\title{
ISLAMIC EDUCATION AND RELIGIOSITY: Voices of the Indonesian Muslim Communities in Australia
}

\section{Teuku Zulfikaria, Emawati ${ }^{2 b}$}

${ }^{1}$ Universitas Islam Negeri (UIN) Ar-Raniry, Aceh

2Universitas Muhammadiyah Aceh

Email: ateuku.zulfikar@ar-raniry.ac.id; bemawati@unmuha.ac.id

1aCorresponding Author

\begin{abstract}
Indonesian Muslims have made their presence in Australia since the 1970s. Some of them now have become citizens and others preferred to be permanent residents. As they have lived in Australia, in which Islam is not the dominant religion, they were concerned with their children's religiosity. These Muslims attempted to teach Islam to their children in any way possible. This research, therefore aims at exploring Indonesian Muslims' parents' ways of teaching Islam to their children, and their children's responses on their parents' approaches in educating them Islam. Using in-depth interviews, the study unveiled that the parents used various aproaches. Their approaches were democratic, in which a great deal of dialogues and neggotiation took place. They also monitored their children's attitudes and kept reminding them about Islam; setting the role models was also a significant approach used in teaching Islam to their children, and balancing the public schooling and the madrasah. The findings also revealed that these young Muslims recognized the significant role their parents have taken to teach them Islam and shape their religiosity and they were thankful for their parents although some dissenting views on several issues also emerged.
\end{abstract}

Keywords: Islamic education, religiosity, young Muslims, Indonesian Muslim parents, Australia

DOI: http://dx.doi.org/10.20414/ujis.v24i1.388 


\section{Introduction}

MUSLIM COMMUNITIES has been flourishing in many parts of the West. ${ }^{1}$ They have lived in those Western countries as citizens or permanent residents. In spite of their long residence in the West, most Muslim parents were still concerned with their children's religiosity. ${ }^{2}$ In this respect, the majority of Indonesian Muslim parents living in Victoria, Australia were found to bear similar concerns.

However, their attempt to teach Islam to their children was not without constraints. Young Indonesian Muslims were exposed to many different values and attitudes in conflict with the Islamic religious texts and doctrines. ${ }^{3}$ In fact, some studies, such as that by Mohammad Akhtar and Moustafa Bayoumi discovered a certain degree of generational conflicts within Muslim communities in the

\footnotetext{
${ }^{1}$ Nahid Afrose Kabir, "Muslim Women in Australia, Britain and the United States: The Role of 'Othering' and Biculturalism in Identity Formation," Journal of Muslim Minority Affairs 36, no. 4 (October 1, 2016): 523-539, accessed May 14, 2019, https://doi.org/10.1080/13602004.2016.1257683; Muhammad Anwar, "Muslims in Western States: The British Experience and the Way Forward," Journal of Muslim Minority Affairs 28, no. 1 (2008): 125-137; Samina Yasmeen, ed., Muslims in Australia: The Dynamics of Exclusion and Inclusion (Melbourne: University of Melbourne Press, 2010); Selcuk R. Sirin and Michelle Fine, Muslim American Youth: Understanding Hyphenated Identities Through Multiple Methods (New York, and London: New York University Press, 2008); Michela Franceschelli and Margaret O'Brien, “'Being Modern and Modest': South Asian Young British Muslims Negotiating Multiple Influences on Their Identity," Ethnicities 15, no. 5 (October 1, 2015): 696-714, accessed May 14, 2019, https://doi.org/10.1177/1468796815584423.

2 Amjad Hussain, "Islamic Education: Why Is There a Need for It?," Journal of Beliefs $\mathcal{E}$ Values 25, no. 3 (December 1, 2004): 317-323, accessed May 14, 2019, https://doi.org/10.1080/1361767042000306130; Jasmin Zine, “Safe Havens or Religious 'Ghettos'? Narratives of Islamic Schooling in Canada," Race Ethnicity and Education 10, no. 1 (March 1, 2007): 71-92, accessed May 14, 2019, https://doi.org/10.1080/13613320601100385; Tess Kay, “Daughters of Islam: Family Influences on Muslim Young Women's Participation in Sport," International Review for the Sociology of Sport (June 29, 2016), accessed May 14, 2019, https://journals.sagepub.com/doi/10.1177/1012690207077705.

${ }^{3}$ Geraldine Doogue and Peter Kirkwood, Tomorrow's Islam: Uniting Age-Old Beliefs and a Modern World (Sydney: ABC Books, 2005).
} 
West. ${ }^{4}$ Mohammad Akhtar, for example found that Muslim youth in the United States have lacked of interest on religious issues. ${ }^{5}$ In fact, it was also found that some young Muslims in Mohammad Akhtar's research perceived that dating and living together of different sexes without marriage were considered as acceptable form of social life. They also perceived that consuming alcohol and smoking were individual choices. In addition, the other striking issue revealed is cultural conflict between the younger and older generation, suggesting that generational conflicts emerge in terms of educational and career choices.

However, Moustafa Bayoumi argued differently, in which he suggested that some young Muslims were found to be more religiously devoted than their parents. ${ }^{6}$ Muslim youth in Brooklyn USA realized that they were vanguards of Islam and they were required to represent it well in the wider American societies. This kind of generational conflict also occurs in terms of religious outfit. The feasibility to wear veil in public is increasing in the contemporary global world, and young female Muslims in research conducted by Syed Ali and Smeeta Mishra \& Faegheh Shirazi choose to take on veil. However, their decision to wear veil is opposed by their family members. Parents of those young Muslims feel senses of insecurity finding out that their daughter wearing veil in the wage of global suspicions toward Muslims. ${ }^{7}$

Given this reality, it is important to note that delivering Islamic education to Muslim youth in the West is complicated. Muslim parents are dilemmatic, whether to strictly require their

${ }^{4}$ Mohammad Akhtar, ed., Muslim Family in a Dilemma: Quest for a Western Identity (Lanham, Boulder, New York, Toronto, Plymouth, UK: University Press of America, Inc, 2007); Moustafa Bayoumi, "Being Young, Muslim, and American in Brooklyn," in Being Young and Muslim: New Cultural Politics in the Global South and North, ed. Linda Herrera and Asef Bayat (Oxford, New York: Oxford University Press, 2010).

${ }^{5}$ Akhtar, Muslim Family in a Dilemma.

${ }^{6}$ Bayoumi, "Being Young."

${ }^{7}$ Syed Ali, "Why Here? Why Now? Young Muslim Women Wearing Hijab," The Muslim World 95, no. 4 (2005): 515-530; Smeeta Mishra and Faegheh Shirazi, "Hybrid Identities: American Muslim Women Speak," Gender, Place E Culture 17, no. 2 (April 1, 2010): 191-209, accessed May 14, 2019, https://doi.org/10.1080/09663691003600306. 
children to abide by all Islamic principles adhered to them or soften their requests to balance the Islamic values and those held in the West. This study therefore, attempted to understand how Indonesian Muslim families and communities played their role as educators in shaping their children's religiosity; whether challenges occurred in their ways of educating their children is also an important part of this study. In this study we also intended to scrutinize if Indonesian-Australian young Muslims in this study perceive being in the family and the Indonesian Muslim communities as significant toward their religiosity development.

To answer our inquiries, we shall develop research questions as follows: how do Indonesian Muslim families play roles in educating their children? What challenges do they encounter in doing so? How do their children perceive the significance of Islamic education they receive from their parents and their Muslim communities?

These questions were investigated through an ethnographic study, in which it explored Muslim parents and the ummah's roles and strategies in educating Islam to their children. It explored if challenges took place in their ways of educating Islam. To answer our inquiries we invited twelve young Indonesian Muslims living in Australia and one of their parents. These young Muslims were the eleventh and twelfth graders, and eleven of them went to Australian public schools, and only one of them went to a private Islamic school. This study therefore, interviewed 18 participants (12 young Muslims and 6 parents). To generated data, we interviewed the twelve young Muslims on learning Islam. We also interviewed the six parents and visited their houses. This fieldwork was conducted in 2010 among the Indonesian Muslim communities in Melbourne. It was privilege for us to have been able to interact with parents and their youth in the Indonesian Muslim community center. Our presence in the center allowed us to gain more insights on these parents' aspiration on the teaching of Islam to their children, and responses of their children.

To analyze findings, the data from interviews were first transcribed and then analyzed through coding techniques. We referred to David Silverman's data analysis technique, in which we used open, axial and selective coding. The codification of the 
transcript allowed us to map and organize data relevant to our research questions. We used all pseudonyms in our presentation of the data.

\section{The family and the ummah: social and educational sites}

The teaching of the Qur'an and the Hadith has made clear that Muslims are required to establish family through Islamic legal binding in a form of marriage. For example, the Qur'an Sūra alRūm [30]: 21 says that:

And among His signs is this: He created for you spouses from ourselves that you might find rest in them, and he ordained between you love and mercy".

Allah has created spouses to all mankind, with whom they establish family units and harvest happiness, and nurture their children. The family unit is an important institution where human beings are raised and educated; and it is a "cornerstone of Muslim society" 8 . The Qur'an states that men and women are created equal; likewise, there are no significant differences between husbands and wives in the Muslim families. Husbands and wives bear similar responsibilities to ensure their children's physical, emotional and educational needs are sufficiently fulfilled.

In addition, Islamic teachings stipulate the importance for Muslim parents to teach their children Islam such as regarding the 'ibādah; the competence in reciting the Qur'an; and regarding good conduct. Cooperation between spouses are needed to ensure that their children are capable of reciting the Qur'an and having good conduct ${ }^{9}$. In addition, Muslim parents are also expected to teach Islam through modeling. For example, they should do șalāh or the sawm first themselves prior requesting their children to do so. This suggests that education in the Islamic point of view needs to start from home. In addition, parents should become

8 Tehmina N. Basit, "'I Want More Freedom, but Not Too Much': British Muslim Girls and the Dynamism of Family Values," Gender and Education 9, no. 4 (December 1, 1997): 425-440, accessed May 14, 2019, https://doi.org/ $10.1080 / 09540259721178$.

${ }^{9}$ Ekram and Mohamed Rida Beshir, Meeting the Challenge of Parenting in the West: An Islamic Perspective, 4th ed. (Beltsville: Amana Publication, 2009). 
professional teachers in teaching Islam, ${ }^{10}$ to enable children to absorb knowledge easily.

Islam recommends certain important values to teach. First and the foremost, parents should teach their children about honesty, since it leads to sincere faithful to Allah. Second is to encourage their children to observe the ibadat such as the saläh and the sawm, and third improve their children's behaviour, since it is one of the essences of the Islamic teaching. This is so because speaking softly and the restriction to be pretentious is the example of Allah's command toward the perfection of behaviour.

In addition to parents' obligation to their children, Muslim children are also strongly advised to treat their parents with respect and avoid speaking harshly to their parents and elders, since being disrespectful is considered one of the greatest sins in the Islamic teaching. The Qur an also gives clear guidelines on the obligation of children toward their parents.

Allah said in sūra al-Isrā' [17]: 23-35 that:

Your Lord has decreed that you worship non but Him, and that (you show) kindness to parents. Should one or both of them attain to old age with you, Say not "Fie" unto them nor repulse them, but speak unto them a gracious word. And lower unto them the wing of submission through mercy and say: My Lord! Have mercy on them both as they did care for me when I was little. Your Lord is best aware of what is in yourselves. If you are righteous, then Lo! He was ever forgiving unto those who turn unto Him.

However, Muslim families living in non Muslim countries may encounter challenges that hinder them in raising their children in accordance with the Islamic principles. Cultural values of the host countries and their policies maybe in conflict with cultural and religious values brought by Muslim immigrants, and thus create some difficulties in Muslim parents' ways of acting upon these Islamic principles. ${ }^{11}$

10 Sunita Mahtani Stewart et al., "Perceptions of Parents and Adolescent Outcomes in Pakistan," British Journal of Developmental Psychology 18, no. 3 (2000): 335-352, accessed May 14, 2019, https://onlinelibrary.wiley.com/ doi/abs/10.1348/026151000165733.

${ }^{11}$ Ekram and Beshir, Meeting the Challenge of Parenting; Mohammad Akhtar, ed., "The Identity Conflict for Muslims in the West," in Muslim Family in a 
In addition to family as one of the significant environments for the formation of religiosity, the Muslim community or the ummah is believed to be the central venue of identity construction. ${ }^{12}$ The Muslim community, known as the ummah shapes Muslim identity. ${ }^{13}$ As Muslim family practices are governed by shari'a (Islamic law), practices within Muslim communities are also guided by the shari a, and that religious centres such as mosques and madrasah are religious communal spaces for the worship of the Muslim ummah. These spaces are also social and educational settings where transmission of religious knowledge from religious teachers and community members occurs. ${ }^{14}$ Cultural and social events also take place within these spaces so as to foster a sense of solidarity and community amongst Muslims. Riaz Hassan, sees it as:

...the ummah can be viewed as collective identity...individuals developed it by first identifying with values, goals and purposes of their society, and then by internalizing them. This process, besides constructing individual identity, also constructs the collective identity. Rituals and ritualised behaviours of the society further reinforce it and give the members a sense of similarity, especially against 'Others' whose collective identities are different. ${ }^{15}$

Dilemma: Quest for a Western Identity (Lanham, Boulder, New York, Toronto, Plymouth, UK: University Press of America, Inc, 2007); Anita Harris and Ameera Karimshah, "Young Muslims, Stigma and the Work of Normality," Sociology 53, no. 4 (August 1, 2019): 617-633, accessed December 14, 2019, https://doi.org/10.1177/0038038518800632; Mohammed Sartawi and Gordon Sammut, "Negotiating British Muslim Identity: Everyday Concerns of Practicing Muslims in London:," Culture E Psychology (December 11, 2012), accessed May 14, 2019, https://journals.sagepub.com/doi/10.1177/1354067X12456714.

12 Claire Tinker and Andrew Smart, "Constructions of Collective Muslim Identity by Advocates of Muslim Schools in Britain," Ethnic and Racial Studies 35, no. 4 (April 1, 2012): 643-663, accessed May 14, 2019, https://doi.org/10.1080/01419870.2011.577899.

${ }_{13}^{13}$ Riaz Hassan, Inside Muslim Minds (Carlton: Melbourne University Press, 2008); Yasmeen, Muslims in Australia.

${ }^{14}$ Rachel Woodlock, "Praying Where They Don't Belong: Female Muslim Converts and Access to Mosques in Melbourne, Australia," Journal of Muslim Minority Affairs 30, no. 2 (2010): 265-278.

${ }^{15}$ Hassan, Inside Muslim Minds, 314. 
This suggests that Islamic center is a central venue to shape Muslims' religiosity, and thus Muslim communities, especially those in the West establish the masjid (mosque) and the madrasah (weekend or Qur'an school) as the important educational sites.

In addition, family and the ummah as the social and educational sites do not only function to prepare Muslims, especially their young generation's cognitive ability but also to train their affective maturity. For example, Harriet Becher found in his study that south Asian Muslim families assign a particular time, which they called the 'sacred time' for religious purposes, such as for the performance of the salat. All members of the families as indicated in Harriet Becher's study need to pay attention on these sacred time, in which they have to retreat from daily routine of their work to perform the salat, which is done five times a day. ${ }^{16}$ Likewise, the religious spaces within the ummah also regularly make a notice when the time for the salat through the calling of adhan (the call for prayer). The necessity to observe these sacred times is a venue to discipline Muslims and this is an educational process.

\section{The essence of education: The Islamic perspectives}

In the attempt to play their role as educators, the Muslim families are required to understand the essence of education in Islam. There are three interrelated terms of Arabic words conveying some common meanings: Tarbiyya, $T a^{\prime} d \bar{l} b$ and $T a^{\prime} l \bar{l} m$ are used to unpack Islamic concept of education. ${ }^{17}$ Tarbiyya is an Arabic word derived from the root word $r a b \bar{a}$, meaning to grow or to increase people's potential and shape them to be 'good'

${ }^{16}$ Harriet Becher, Family Practices in South Asian Muslim Families: Parenting in a Multi-Faith Britain (New York: Palgrave Macmillan, 2008).

17 Syed M. Naquib Al-Attas, "Preliminary Thoughts on the Nature of Knowledge and the Definition and Aims of Education," in Aims and Objectives of Islamic Education, ed. Syed M. Naquib Al-Attas (Jeddah: King Abdul Aziz University, 1977); Susan L. Douglass and Munir Shaikh, "Defining Islamic Education: Differentiation and Applications," Current Issues in Comparative Education 7, no. 1 (2004): 5-18; J. Mark Halstead, "Toward a Unified View of Islamic Education," Islam and Christian-Muslim Relations 6, no. 1 (1995): 25-43; Muhaimin, Nuansa Baru Pendidikan Islam: Mengurai Benang Kusut Dunia Pendidikan (Jakarta: RajaGrafindo Persada, 2006). 
Muslims as prescribed by Allah Tarbiyya aims to perfect students' soul. $T a^{\prime} d \bar{\imath} b$, which derives from its root aduba means "to be refined, disciplined, cultured", which functions to shape students' moral discipline. The last term, $t a^{\prime} l \bar{l} m$, from the root word 'alima means "to know, be informed, perceive, discern", which refers to the process of transferring knowledge. The process of $t a^{\prime} l i m$ shall enable students to reach the stage of spiritual consciousness and intellectual empowerment, which leads student to imān (faith), 'amal sālih (virtuous acts), and yaqin (certainty about their faith).

The integration of these three terms reflects the aim of education in Islamic concept, which is to perfect Muslims' soul, body and mind. In addition, Islam conceives education as the venue of students' spiritual, corporeal, and intelligent empowerment, which does not merely function to prepare mankind to reach happiness in this world but also helps students to reach a certain level of spirituality that leads to eternal happiness in the akhirāt or life in the hereafter ${ }^{18}$, since acquiring both intellectual and spiritual knowledge will enable mankind to perform their role as khaliffah Allāh fi al-ard (Allah's vicegerent on earth).

To achieve this goal, parents as educators are encouraged to be murābbì, mu'äddib, and mu'ällim (all of these terms referring to teachers and educators) at home. In terms of teaching methods, Islam suggests that while parents are required to understand their children's emotional and physical conditions and expectations prior to engaging in instructional process, Muslim children are recommended to respect their parents as the learned and the wised. Parents as teachers are required to speak at the level of their children's' knowledge, empower them, nurture their intellect to gain confidence, and tolerate their children.

In addition, Islam also requires Muslim parents to encourage their children to pursue knowledge. Some Hadith convey this message: For example, the Prophet Muhammad asserts that 'seeking knowledge is an obligation for all Muslim men and

${ }^{18}$ Hamid Reza Alavi, “Nearness to God: A Perspective on Islamic Education, Religious Education," Religious Education: the Official Journal of the Religious Education Association 103, no. 1 (2008): 5-21. 
Muslim women'. The Prophet Muhammad also requires the adherents of Islam to seek knowledge starting from the cradle to the grave. ${ }^{19}$ This indicates that the pursuit of knowledge in Islam is a life-long journey. In addition, the main source of Muslim faith, the Holy Qur'an highly values ilm (knowledge) and put the great values on the learned people. Islam suggests that ilm correlates with the imann, since to have a strong faith, Muslims are expected to acquire a depth knowledge as the foundation for their īmān. This suggests that Islam expects its adherent to seek knowledge. This is reflected from the first verse revealed to the Prophet Muhammad. Allah said in Sūrah al-Alāq [96]: 1-5:

Read! In the Name of your Lord Who created. He has created man from a clot. Read! And your Lord is the Most Generous. Who has taught by the pen. He has taught man that which he knew not.

These ayāt indicates that Islam requires Muslims to engage in constant reading to gain not only ilm (knowledge) but also hikma (wisdom). In the other instance, Allah surely states that those who have knowledge are of great values in the eyes of Allah. The Qur'an Sūrah al-Mujādilah [58]: 11 says that:

Allah will exalt in degrees those of you who believe, and those who have been granted knowledge. And Allah is Well-Acquainted with what you do.

Ibn Kathir explains that this ayāt explain that Allah exalts the position of those who posses knowledge higher than those who are ignorant.

The Islamic concepts of education in a way construct Muslims' religiosity. For example, the requirement to respect teachers, positions Muslim students in different corner from those who are not engaged in the Islamic educational system. In addition, the Islamic concept on education, which emphasizes the fulfilment of intellectual, corporeal and spiritual knowledge, shapes Muslim students' ways of engagement in educational settings. In spite of the aim of education in Islam, which is to create the perfection of

19 Eric Hilgendorf, "Islamic Education: History and Tendency," Peabody Journal of Education 78, no. 2 (April 1, 2003): 63-75, accessed May 14, 2020, https://doi.org/10.1207/S15327930PJE7802_04. 
mankind, young Muslims living in the West may be exposed to different educational values, which are not necessarily recognized in the Islamic concept of education. ${ }^{20}$

\section{Meeting Muslim families}

This section briefly introduces Muslim parents and the Muslim youth participated in the study. This is important to provide significant background of these Indonesian Muslim families living in Victoria, Australia to give insights on the object of the research.

The parents of all these twelve students are Indonesian Muslims except Zaki's mother and Yudi's father who are of the Anglo-saxon background converted to Islam. They come from families working in many different fields: factories, academic staff, government employee, and bussiness. For example, Heriati's parents own a small halal café and Bakri's father is a professional plumber, Salmi and Imam's parents are academic staffs. Most of the mothers of these young Muslims are housewives, except Zaki's mother who works in City Council, Icha's mother works in Health Service Centre, and Fatma's mother, a university professor.

The parents of some of them migrated to Australia in the 1970s and some in the 1990s, and some migrated to Australia for the educational purposes. These parents admitted that being in Australia was a privilege for them as they had better living and better education for their children. Bakri's father, for example argued that he was more comfortable living in Australia, since he himself has been in Australia since teenager. He asserted:

I have tried to live in Indonesia, but I feel more comfortable living here in Australia, in which I could make a good living, and raise my children. ${ }^{21}$

Although living in Australia allowed these Muslim parents to obtain sufficient income, they were concerned with their children's religiosity. Amin, for instance raised this issue:

20 Bradley Cook, “Islamic Versus Western Conceptions of Education: Reflections on Egypt," International Review of Education 45, no. 3-4 (May 1, 1999): 339-357.

${ }^{21}$ Interview with Oka, Bakri's father, July 252010 
I have a grave concern with my son's religiosity, but I believe that environment shapes one's identity. If he is in the Muslim environment, he will be exposed to Islamic values, I also teach him Islam through story-telling, especially the story of the Prophet Muhammad, and I also encourage him to read Islamic books. Lastly, I make a do'a [pray] to Allah to guide my son. ${ }^{22}$

This concern applied to all Muslim parents in this study. They were aware that Islam requires them to shape their children's religiosity and guide them to the path which is in accordance to the Islamic teaching. The Qur'an and the Hadith have set certain principles on parents' obligations toward their children. As required by Islam, parents are invited to be the murabbi, mu'addib, and the mu'allim to their children, which then enable them to perfect their children's soul, body and mind.

In addition, referring to Yasmeen's ${ }^{23}$ Muslim typologies, the Muslim parents of these young Muslims are practicing moderate Islam. Heriati also stressed this point:

...you got the orthodox and you got the moderate, I think we fall into the moderate, if we draw the line between fundamentalism and moderate, we close to moderate..$^{24}$

These parents were involved in the Indonesian Muslim community centre and were active at attending the religious sermons there and also those taking place within homes of Indonesian Muslim community. For example, Amin, Zaki's father, attended the Islamic sermons took place on Friday nights, Saturday nights and Sunday mornings. While in the mosque I found him performing the Șalāh in congregation, and the commitment to pray is one of the markers of practicing Muslims as suggested by Riaz Hassan. ${ }^{25}$ Zaki's mother, however, rarely attended the mosque. Bakri's parents attend the Islamic sermons run on Friday nights. Joni, Heriati's father and Hanti, Fatma's mother, Eko, Haikal and Hardi's father attended the religious

22 Interview with Amin, Zaki's father, June 21, 2010.

${ }^{23}$ Samina Yasmeen, ed. Muslims in Australia: The Dynamics of Exclusion and Inclusion. Melbourne: University of Melbourne Press, 2010.

${ }^{24}$ Interview with Heriati, Year 12, June 24, 2010.

${ }^{25}$ Hassan, Inside Muslim Minds. 
sermons taking place on Sunday morning, and when Joni was in the mosque, he frequently became the muadzin (the caller for the saläh) while her mother only occasionally attended this religious space. Icha and Sari's parents only occasionally visited the Indonesian mosque during regular Islamic teaching. However, they attended the mosque during special events taking place there, especially in the month of Ramadhan.

Unlike the other parents who live nearby the Indonesian Muslim community center, the parents of Yudi, Salmi and Imam lived further away, and thus they were not made a visit to the Indonesian mosque on regular basis. However, during the major Islamic festivals and congregation, they oftentimes visited the Indonesian Muslim mosque.

\section{Islamic Education and Religiosity: The Parenting Roles}

This section elaborates Muslim parents' strategies in instilling Islamic education to their children, which shape these youth religiosity.

\section{Great concern}

The interview showed that constructing and maintaining children's religiosity was a concern for all Muslim parents living in the West. ${ }^{26}$ Although they lived far away from their countries, Muslim parents living in a minority Muslim country attempt to migrate their cultural and religious values with them ${ }^{27}$ and transferred these values to their children, and such action should start from home. This issue was also the concern of all parents in this study. Toni, Sari's father speaks regarding this issue:

The most effective ways of teaching children is to start from home, and then I sent them to Sunday school. However, after they graduated from

${ }^{26}$ Becher, Family Practices; Bruce A. Collet, "Islam, National Identity and Public Secondary Education: Perspectives from the Somali Diaspora in Toronto, Canada," Race Ethnicity and Education 10, no. 2 (July 1, 2007): 131-153, accessed May 14, 2019, https://doi.org/10.1080/13613320701330668; Rima Bern McGown, Muslim in the Diaspora: The Somali Communities of London and Toronto (Toronto, Buffalo, London: University of Toronto Press, 1999).

27 Tehmina N. Basit, Educational, Social and Career Aspiration (Cambridge: University of Cambridge, 1995); Becher, Family Practices, 101. 
primary school, they were reluctant at coming to the school [madrasah]. I also show them that they are Muslims, in which Muslims are obliged to fast and to pray, and we should be committed to show non Muslims about the Islamic values. ${ }^{28}$

These young Muslims also see parenting roles as significant in the formation of their religiosity. These roles range from reminding them about Islam. One of them, for example asserts:

It's important that my parents remind me everyday how lucky I am, like if we see on TV, they remind me about Allah and anything...Ya my parents are the most because they come here like 25 more years ago, and they would be as many Muslim here as it were then so life is even harder back then and now I got pretty easy toward they had it and yea I realize that... ${ }^{29}$

I think it is my family, like how they brought me up; it is a big part and I realize yeah this is [Islam] the right way. ${ }^{30}$

As these Muslim parents believed that effective education starts from home, they took various teaching roles at home. Some stated that accompanying children to learn about Islam or 'being there' to borrow Becher's term, for their children was an effective way of teaching. Hazny, for example stated:

I usually give a special care for Fatma. She is different from her sisters. She grows up here in Australia and lives in the Australian environment, in which she interacts with mostly non-Muslim friends. Sometimes, I read Islamic books for her because I believe that the attempt in shaping children's Muslim identity should start from home. I have to negotiate my ways of teaching her about Islam. ${ }^{31}$

As we see from the comments, the parents realized that the discourse of 'being there' is important to shape Muslim identity of their children. Hazny believed that the home environment was the first educational site for every child, and thus she spent times reading Islamic books with her children.

Other parents act as a role model for their children, as Deni and Eko reveal:

\footnotetext{
${ }^{28}$ Interview with Toni, Sari's father, June 24, 2010.

${ }^{29}$ Interview with Sari, 10 June 10, 2010.

${ }^{30}$ Interview with Bakri, May 20, 2010.

${ }^{31}$ Interview with Hanti, Fatma's mother, June 28, 2010.
} 
We have to be the role model for them. I invite them to pray in congregation, but I realize when they are grown up, it is difficult to ask them to pray together. However, we always remind them about the salāh and the zakāh.... Unfortunately, I do not have sufficient Islamic knowledge, so I just teach them about wisdom. ${ }^{32}$

Parents should be the role models for them. If we are going out, when it is the time for prayer, we immediately perform the salāh, and they join with us too. They have got used to doing the salāh in public. ${ }^{33}$

For these Muslim parents one of the important parenting roles to exercise is modelling. They suggested that when asking their children to perform the șalāh, they invited them to do it together in congregation. They showed that they also performed the Islamic rituals. This strategy allowed their children to imitate their practice. The strategy used by these Muslim parents was in line with Ekram and Beshir's suggestions. However, they were also aware that when their children grow up, they found it more challenging to invite them to pray in congregation. The parents told me that when their children reached secondary level, they did not always follow the parents' requests. Their reasons varied. Some indicated that they were fully occupied with school work and thus did not have time to attend the mosque to listen to sermons about Islam.

\section{Differentiated Approaches}

Our study revealed that Muslim parents used various approaches in teaching Islam to their children: avoiding coercion; monitoring actions; and showing role models. We shall elaborate in more details regarding these approaches in the following discussion.

First, all these parents argued that they would avoid coercion in their approaches in any ways possible. They believed that coercion was harmful. The following quotes discussed how Muslim parents in this study approached their children when teaching them Islam. The following quote suggested their parenting styles. Oka asserts:

\footnotetext{
${ }^{32}$ Interview with Deni, Salmi and Imam's father, June 17, 2010.

${ }^{33}$ Interview with Eko, Haikal and Hardi's father, 15 June 15, 2010.
} 
I don't force my children, I teach them Islam through dialogue, I have a chat with them about the Islamic principles; about what they should do and should not do as Muslims. ${ }^{34}$

Oka articulated that his children will understand Islam much better if he approached them through dialogue. He insisted that he used reasoning in teaching his children about Islam. For example, upon teaching his children about some restrictions in Islam, such as alcoholic drink, male-female relationship and other kinds of religious issues, he justified through logic examples to help his children understand better.

Likewise, other Muslim parents share this understanding. In fact, they were aware that child corporal punishment as illegal and impermissible in Islam and in the Australian society as well. Amin then articulated:

I teach about Islam regularly and slowly, I don't force him, I have to be more patient in instilling Islam to him. Praise be to Allah with the help of Allah, hopefully I am able to teach him Islam and to maintain his Muslim identity. ${ }^{35}$

In terms of type of attire for instance, some of the parents did not seem to set strict rules. These parents only emphasized modesty regarding the types of clothes to wear. This suggests that they did not set a strict rule regarding the types of clothes their children choose to wear as long as it showed modesty. In addition, the other instance where coercion is not possible was when asking these students to perform the five time prayers. The parents avoided forcing them to observe the religious rituals, such as the saläh and the sawm; rather they raised their children's awareness that they actually belong to the Islamic faith, and that they needed to fulfil their religious obligations.

Second, these Muslim parents monitored their children's behavior. These parents might not force their children to abide by all Islmic principles, but they should be made aware of some underlining principles in Islam. Therefore, some parents noted that whenever their children showed disrespect toward them, they

\footnotetext{
${ }^{34}$ Interview with Oka, Bakri's father, July 25, 2010.

${ }^{35}$ Interview with Amin, Zaki's parents, July 4, 2010.
} 
reminded them about the Islamic values to which they should commit. Salmi and Imam's father, for example noted:

They sometimes act like Australians, if they have gone too far in their behaviour, I would tell them that we have our own values. I realized it was difficult to control them indeed, I just make a do'a [to Allah]. ${ }^{36}$

This narration suggests that Deni and some other parents tried to build good relationships with their children. However, if their children showed disrespectful attitudes, Deni and other parents reminded them to behave well. In addition, they told me that one of their responsibilities as parents was to shape their children's attitudes, so that they know about being modest upon interacting with others.

All parents believe that dialogue is the most acceptable ways of teaching Islam to their children. In fact Islam requires Muslim parents to understand their children's 'psychological mechanism' during their engagement in parenting roles. They further discuss:

In order to know how to motivate children to function a useful and cooperative way, we must have some understanding of the psychological mechanism involved.... A child has two major motives that drive his or her actions-the need to belong and the need to gain attention. ${ }^{37}$

In the Qur'an, sūrah al-Naḥl ayāt 125, Allah reminds Muslims to be gentle and wise in their ways of preaching someone about Islam, and this also applies to Muslim parents who engage in their parenting roles. Allah says: Invite the way of your Lord with wisdom and kind advice.

Gentleness and brevity in teaching has been practiced by the Prophet Muhammad, and thus Muslim parents are invited to take His footstep because this kind of teaching does not only yield positive result but also allow them to build good relationship with their children.

In addition, Muslim parents faced much greater challenge because their children were born and or raised in Australia, a non Muslim country, in which Islamic environments and facilities that

\footnotetext{
${ }^{36}$ Interview with Deni, Salmi and Imam's father, June 20, 2010.

${ }^{37}$ Ekram and Beshir, Meeting the Challenge of Parenting, 17.
} 
nurture their children's religiosity are rare. As they were born and raised in Australia, they live within multiple settings within the broader Australian societies. They also interacted with wide diversities of ethnicities and nationalities. Their exposure to the attitudes that are in conflict with the Islamic law is paramount in the lives of some of these young Muslims. For example, on the one hand, Islam prohibits all Muslims to engage in sexual relationship prior to marriage; Islam also forbids Muslims to drink alcohol; and Islam does not allow its adherents to talk harshly with their elders. On the other hand, these young Muslims observed their friends engaging in some activities, which were prohibited by Islam. These conflicting realities position these young Muslims in dilemma between adhering to the Islamic rules and negotiating the pressure of in their surroundings. This kind of dilemma is not unusual, other studies, such as by Tehmina N. Basit and Nahid Afrose Kabir have shown similar points. ${ }^{38}$

Given these complex realities, these Muslim parents were aware of the challenges facing them and thus extra care should be measured to enable them invite their children to see Islam as their way of life. These youths should be always reminded about their origin. Rahmat, for example asserts:

I told them that they only born here in Australia, while we originated from the village [the countryside]. My oldest son has visited Indonesia frequently, and Ika has visited Indonesia 3 times. ${ }^{39}$

In the same token, Amin suggested that:

The key procedure in instilling Islam to him is to remind him of his background that he is a Muslim, 'Muslim is your religion', and he is proud to be a Muslim and did not hide his Muslim identity, and thus gains respect from his friends. He also takes care of the dietary issue-the halal food. ${ }^{40}$

Although they wanted their children to be righteous Muslims, some of them did not set a high standard on the level of their children's religiosity because they realized that it was difficult for

38 Basit, Educational; Nahid Afrose Kabir, Young British Muslims: Identity, Culture, Politics and the Media (Edinburgh: Edinburgh University Press Ltd, 2010).

${ }^{39}$ Interview with Rahmat, Icha's father, May 15, 2010.

${ }^{40}$ Interview with Amin, Zaki's father, July 4, 2010. 
them to expect their children took all markers of 'good' Muslims. This was because raising their children as Muslims in a minority Muslim country like Australia was very challenging as it had been noted earlier.

Toni and Joni, for instance raised this issue:

I asked them to come to the mosque in order that they could hear the azan [the call for prayer], through which they would be aware of their Muslim identity. ${ }^{41}$

At least Heriati is aware that she is a Muslim. I also expect that she understands some Islamic rules and regulations that she is not allowed to break, and I notice that she is aware of these Islamic rules. ${ }^{42}$

Because of their children did not live in vacuum, they interacted with friends from many ethnic and religious backgrounds, it was difficult for them to expect their children to be devoted Muslims. For some of them, it was sufficient that their children were aware of their belonging to the Muslim ummah.

These parents believed that home environment was an important source of identity formation, and thus constant reminding their children about their religious background is significant in shaping the Muslim identity of his children.

Some of them, Oka expressed his concern:

At home, I have to keep reminding my children about Islam, I cannot stop doing that...youngsters in the age of 15-16-17 are having a critical change in their personality...it is a common thing in Australian that almost every weekend, teenagers go to party. ${ }^{43}$

This information suggested the degree of concern that parents had in regard with teenager social life in Australia. Issues of lifestyles were of great concern for these Muslim parents.

Third, setting the role model. All parents realized that setting role model to their children was a significant part of educational system that all parents should considering doing. Eman, Dini's father, for example stated:

\footnotetext{
${ }^{41}$ Interview with Toni, Sari's father, July 10, 2010.

42 Interview with Joni, Heriati's father, July 20, 2010.

${ }^{43}$ Interview with Oka, Bakri's father, July 25, 2010.
} 
I learn how other parents exercise their parenting roles. I found that most parents do not teach Islam to their children as early as possible and they tend to be forceful in their teaching ... I do not have a certain theory in educating my children, I only ask help from Allah, the second thing that I do is that I don't only ask them to practise the religion, we also practise our religion. I have never forced her to do things; I just encourage her to practise Islam. If she wanted to put on the jilbab, she should do it immediately by the time she enters a secondary school. ${ }^{44}$

The quote suggests he had various ways of exercising his parenting roles at home. First, he asked Allah's helps to give him strength to teach his children about Islam. He said:

I always pray to Allah to help me guide my children and turn them to be righteous Muslims. Since they were small we talk about sinful activities. We ask them to pray and we model it at home too. For Dini, she puts on veil. I really thank Allah for that. I have never forced her to wear the jilbab. I only encourage her to put on veil from early on before she enrols in high school. ${ }^{45}$

He was very consistent at reminding his children about Islam and performing the Salāh at home. He insisted that guarding children's 'ibādah is parents' obligation in Islam. He asserted:

I perform the șalāh in Jamaah [in congregation] but not always. Every morning I wake them up to do the Morning Prayer otherwise [I will be blamed]. ${ }^{46}$

The preceding comment shows Eman's efforts at instilling Islam in his children. He was active and proactive in reminding his children about the religious rituals. In fact, he was committed at waking his children up for the Morning Prayer. Besides encouraging his children to perform the religious rituals, he also sometimes gave a short speech about Islam after the sunset prayer. In addition, he was committed to allocating 'sacred time', when he requests his children to engage in the recitation of the Qur'ān nightly.

In addition, as these Muslim parents believed that effective education starts from home, they took various teaching roles at

\footnotetext{
${ }^{44}$ Interview with Eman, Dini's father, July 25, 2010.

${ }^{45}$ Ibid.

${ }^{46}$ Ibid.
} 
home. Some stated that accompanying children to learn about Islam or 'being there' to borrow Harriet Becher's term, ${ }^{47}$ for their children was an effective way of teaching. Hanti, for example stated:

I usually give a special care for Fatma. She is different from her sisters. She grows up here in Australia and lives in the Australian environment, in which she interacts with mostly non-Muslim friends. Sometimes, I read Islamic books for her because I believe that the attempt in shaping children's Muslim identity should start from home. I have to negotiate my ways of teaching her about Islam. ${ }^{48}$

As we see from the comments, the parents realized that the discourse of 'being there' was important to shape their children's religiosity. Hanti believed that the home environment was the first educational site for every child, and thus she spent times reading Islamic books with her children.

Other parents also acted as a role model for their children, as Deni and Eko revealed:

We have to be the role model for them. I invite them to pray in congregation, but I realize when they are grown up, it is difficult to ask them to pray together. However, we always remind them about the șalāh and the zakāh.... Unfortunately, I do not have sufficient Islamic knowledge, so I just teach them about wisdom. ${ }^{49}$

Parents should be the role models for them. If we are going out, when it is the time for prayer, we immediately perform the șaläh, and they join with us too. They have got used to doing the șalāh in public.50

For these Muslim parents one of the important parenting roles to exercise is modelling. They suggested that when asking their children to perform the salāh, they invited them to do it together in congregation. They showed that they also performed the Islamic rituals. This strategy allowed their children to imitate their practice. The strategy used by these Muslim parents was in line with Ekram and Mohammed Ridha Beshir's suggestions. However, they were also aware that when their children grow up,

\footnotetext{
${ }^{47}$ Becher, Family Practices, 101.

${ }^{48}$ Interview with Hanti, Fatma's mother, July 27, 2010.

${ }^{49}$ Interview with Deni, Salmi and Imam's father, 22 July 22, 2010.

${ }^{50}$ Interview with Eko, Haikal and Haidar's father, June 15, 2010.
} 
they find it more challenging to invite them to pray in congregation. The parents told me that when their children reached secondary level, they did not always follow the parents' requests. Their reasons varied. Some indicated that they were fully occupied with school work and thus did not have time to attend the mosque to listen to sermons about Islam.

\section{Balancing weekend school and Public schooling}

Our interviewed with parents revealed that they sent their children to Australian public school for several reasons: the integration and the quality issues. These were two main reasons for these parents to send their children to public schools. The was their argument that public schools allowed their children to have a balance life. Some of the parents, for example raised this issue:

I don't intend to send my children to Islamic schools, since I don't agree with segregated religious schools...I told my children that we live here in Australia, we have to have a balance life and understand how other people's ways of life..$^{51}$

I want to give a chance to my children to interact. I told them 'you are Muslims' so just go and interact with people around you be they Muslims or not. I believe that schooling is one of the best places to develop such interactions. There are only two consequences of this interaction, first, either my children will give a good example to their friends and influence their friends or they get influenced, and fortunately, so far my children are able to influence their friends, or at least are able to guard their Muslimness..$^{52}$

Some of the parents in this group believed that public schools helped their children to integrate with mainstream Australian society. They in fact suggested that their children did not show any sign of discomfort being at their school. Some of them reiterated that public schools accommodate religious differences.

The other important reason was school quality. Oka, for instance asserted:

We are not against Islamic school. We just felt more convenient sending children to public school. In fact, I don't see a big difference between

\footnotetext{
${ }^{51}$ Interview with Toni, Sari's father, July 10, 2010.

${ }^{52}$ Interview with Oka, Bakri's father, July 25, 2010.
} 
Islamic and non Islamic school, to me all of them are the same. Why this special public school? Because academically, it is a prestigious school in the area. ${ }^{33}$

Academic rank or school quality seemed to be some of the first reasons Muslim parents in this group sent their children to public school.

As these parents also realized that public schools did not cater religious learning, they balance their children's being in public schools with participation in the Islamic center or and the Islamic weekend school. As a part of teaching Islam to their children, the parents invited them to the madrasah held in the Islamic center or the Indonesian mosque. They seemed to put a lot of efforts taking their children to gain Islamic lesson in the weekend schools or the madrasah held in the mosque. They also took their children to weekly and monthly Islamic learning circles and asked them to fulfil their religious duties.

Fatma's parents, for instance, invited her to attend the Sunday morning learning circle. Although she was not very enthusiastic about attending the mosque for that purpose, her parents seemed to be consistent in their request. Hanti asserted:

I used to attend the pengajian run on Friday nights, I also joined the one on Sunday morning, and then I preferred to come to the Sunday one. I also used to invite my children to come along with me but it was difficult to invite Fatma because she tends to compare [with other friends who did not come to the mosque].54

In the non-Muslim country like Australia, the weekend school or the madrasah is a central point, in which the Islamic education take place. This is because the madrasah facilitated young Muslims to learn a wide range of Islamic issues; especially Qur'anic recitation, Islamic history, Islamic jurisprudence, and also Islamic way of life. The Indonesian Muslims, especially those living in Victoria have established two Islamic centers function as the mosque and sites for Islamic learning circle. The Muslim parents along their children have regularly visited the centers.

\footnotetext{
${ }^{53}$ Ibid.

${ }^{54}$ Interview with Hanti, Fatma'a mother, July 27, 2010.
} 


\section{Home and Islamic: The significant site for education}

The study also reveals that young Muslims in this study were aware that their parents had played their parenting roles to teach them about Islam. Their parents were also remindful about their religion. Some of them described as follows:

Yeah there is a lot of people that influence me to do better things. Like my brother will always remind me if I forget to pray he'll tell me to pray, he just always reminds me, and my parents always remind me to be thankful for everything I have and if you've got no one to turn to you've got Allah, so it's like it reminds you that there's always something there for you, but yeah I think it's a blessing. ${ }^{55}$

In addition, Icha said:

My parents...my parents always remind me to that...not really (do not pray together at home) but during Ramadhan we pray Magrib together...they ask me whether I want to come ...like pray and stuff like that, like I don't know, telling me not to do, like fun stuff and like that. ${ }^{56}$

Heriati also stated that her parents had been significant in the attempt to shape her religiosity. She noted that "mum and dad told us to pray and we have to learn the Qur'an". She stated that the fact that parents asked her and her siblings to behave in accordance to the Islamic rules and also asked her to perform religious rituals meaning that the parents were serious about shaping her religiosity. She also suggested that her parents' expectation on her ability to recite the Qur 'an and that sending her to Islamic private school was one of their efforts to guide and guard her religiosity.

In addition, Indonesian Muslims in this study have distinctive views on attending the Islamic center. Some of them considered the center as beneficial for their learning of Islam and thus increased their religiosity. This was evident from the assertion of the Indonesian young Muslims learned how to recite the Qur'an properly from the center. Hardi, for example said that in the center

\footnotetext{
${ }^{55}$ Interview with Sari, June 10, 2010.

${ }^{56}$ Interview with Icha, June 11, 2010.
} 
I learn to read Al-Qur'an really better now fluently, not much mistake and faster and also learn a bit Arabic and I memorize the meaning of sūrah, and Islamic study like the history of Islam and stuff..$^{57}$

The experience gained in the center was also relevant to many other young Muslims in this study, in which they argued that the have got knowledge on recittaion of the Qur'an from the center rather than from their home environment

Apart from Qur'anic learning, these students also received other kinds Islamic knowledge. Salmi told me that she learnt many things at the center in regard with the history of Islam. Salmi and Sari discussed during the interview that teachers sometimes taught them about the life of prophet and other such history on Islam. In addition to learning history, Dini and Fatma also claimed that the center also catered some issues on relationship in Islam within the Muslim community and also with non Muslims. Dini said:

[I do] a lot of things, probably the issue about boy and girl in Islam, the other week we are discussing about it, my teacher got reference from the Qur'an saying about what should we do what should not to do about the relationship and ya I wouldn't have got that if I didn't go to madrasah. ${ }^{58}$

In this quote, Dini suggested that she learnt a wide range of topic; one of which was about relationship between male and female in Islam. The teachers took some references from the Qur'an to discuss the proper way, in which Muslim build relationship. In line with Dini, Fatma also argued that:

they [teachers] teach us about living in Australia, in this environment, being a Muslim in this environment and stuff like that and how to deal with things in the Muslim way and stuff like that. ${ }^{59}$

This suggested that the center was not only a venue of learning Qur'an per se, but also a place to learn about living in a non Muslim communities according to the Islamic principles. In

\footnotetext{
${ }^{57}$ Interview with Hardi, June 12, 2010.

${ }^{58}$ Interview with Dini, June 13, 2010.

${ }^{59}$ Interview with Fatma, June 14, 2010.
} 
addition to a place of Islamic education, the center a place for social interaction between Muslim intergeneration.

In addition to perceiving the Islamic center as the educatioal site, they considered it as the comfort zone. They felt soothing being in the center learning and interacting with others. These young Muslims feel the bond of brotherhood in the Islamic center, and this what Claire Tinker and Andrew Smart to 'collective identity ${ }^{60}$ Haikal, Salmi and Dini among of them, for example stated that being in the center was different from being in the public schools. This was because it was free from prejudicial thought due to religious affiliation. In the center, they interacted with all Muslim youth, in which religious discrimination was not likely to take place. Haikal told me that:

I feel different because in the center nobody call me a terrorist, they always talk to me and because the teachers are a bit nice, we can talk freely and we can interact, in public school you know some people call me terrorist and in the classroom, the teacher is kind of strict, we cannot communicate, we cannot ask question and help each other out, whereas in the Islamic school, you can do that, you can do both. ${ }^{61}$

Haikal seemed to compare between schooling atmosphere at the Islamic center and the public schools, in which he attended. The absence of prejudicial thought and discriminative act made the center as the comfort zone for them. Similarly, Dini and Salma suggested that they have different feeling being in the center, in which they found peace. Dini stated:

It is more peaceful at the center as well because at school people are not Muslim or Indonesian so they don't understand I guess. In the West, all we can express our opinion on the Islamic stuff and we feel comfortable with each other and at center I am with the people my age, I can discuss stuff that are suitable for my age. ${ }^{62}$

Dini argued that the center gave more peaceful conditions than the public school for several reasons. First, at the center, she interacted with Muslims and most of them are Indonesian

60 Tinker and Smart, "Constructions of Collective Muslim Identity by Advocates of Muslim Schools in Britain," 643.

${ }^{61}$ Interview with Haikal, June 15, 2010.

${ }^{62}$ Interview with Dini, June 13, 2010. 
students who share many things in common. Second, her friends in public school may not be able to fully understand her, since they are neither Muslims nor Indonesians, and third, she suggested that the Islamic center gave her more space to be expressive. Likewise, Salmi suggested how she felt peaceful being with Muslim friends, in which she could talk about many things, she said that:

I need some other environment where I could talk with people who are actually Muslims themselves and share the same belief as me and who are going to the same situation at school so I find that like a kind of a break from the other... Yeah I really-really enjoy actually my Muslim friends... I really like my Muslim friends just because we got such a close bond now ... we just find that we can talk to each other more openly about everything...63

Salmi explicitly expressed how she felt being at the center, in which she developed bondage with other Muslim friends. She also maintained that her Muslim friends know her better than those of in public school, and thus will allow her to discuss many issues with her Muslim friends, which was unlikely so with her Muslim friends.

However, some students indeed expressed distinctive views on being in the madrasah, Two main reasons for these were time constraints and boredom. Some of these young Muslims argued they did not attend the Islamic center for Islamic education was because the time. Icha, for instance state:

My parents force me to go to weekend school but I don't go no more ... I used to go to Islamic weekend school...I just cannot get up in every Sunday morning...probably yea I will attend the weekend school again...Yeah I don't like...like it is all about religion you know, like it is boring, one boring subject. So like normal school you have different other subjects. ${ }^{64}$

I usually not really wanna come because I have homework, usually during the week I am always busy and I won't have time for myself, but if something is very important, I probably go. ${ }^{65}$

\footnotetext{
${ }^{63}$ Interview with Salmi, June 17, 2010.

${ }^{64}$ Interview with Icha, June 11, 2010.

${ }^{65}$ Interview with Heriati, June 18, 2010.
} 
These quotes showed that while some Muslim youth enjoyed joining Islamic education in the Islamic center, these Muslims were not able to always attend the place because of time schedule. Apart from time schedule, two of the young Muslims argued that they got bored learning almost the same issues all year long. Yudi and Imam argued as follows:

I don't learn much from Sunday school really, I don't know, it's just the same stuff every year...Just they teach the same stuff every year every year, just like I have been in the top class like 3 or 4 years now, and it just the same stuff the same stuff, different teachers but the same stuff. ${ }^{66}$

...This year and the year before we have been learning the same things or more mature stuff which is kind of boring I don't know why because it gets the common sense, not to do that, not to do this, that is alright but because our teacher just reads from a book. ${ }^{67}$

The quotes shows justification for not being interested in joing the madrasah. They just could not make up with the time schedule and for some reasons, they found it tedious to learn almost the same thing all years long.

\section{Conclusion}

The study on Indonesian Muslim parents' approaches in teaching Islam to their children has unveiled interesting findings. It revealed that Indonesian Muslim parents were concerned with their children's religiosity, and this shaped the way these parents approached their children in their attempt to teach them Islam. It was evident that they have played roles as murābbì, mu'āddib, and $m u^{\prime}$ allim in teaching Islam to their children. As the murābbì, they did not enforce their children; they try to instill Islamic teaching through winning their children's heart as to abide by all Islamic principles as stipulated in the Qur'an. The mu'allim role was played at home when some of the parents taught Qur'anic recitation to their children. As the data has shown that some parents stated that they have actively taught the Qur'an to their children at home. The parents also played the role of $m u^{\prime} \bar{a} d d i b$ as they consistently took their children to the mosque to learn Islam

\footnotetext{
${ }^{66}$ Interview with Yudi, 19 June 19, 2010.

${ }^{67}$ Interview with Imam, June 20, 2010.
} 
and observe the Islamic values played out at the mosque. The study also suggested that as the parents sent their children to public school where the teaching of Islamic education was not catered, they balanced it by sending these Muslim youths to the Islmic center, in which Islamic learning circle was conducted. Thes findings suggest that Muslim parents in the West negotiated the way they instilled Islam to their children, since these youths were also exposed to mainstream values, which might not applicable to Islam.

This article has codified several approaches used by parents in teaching Islam to their children: avoided coercion, in which dialogues was promoted; monitored their children's actions, and set the role model for their children. However, challenges in playing these roles were obvious. These young children as they also interacted with friends who did not share common faith and culture, might not hold common understanding on standard Islamic characters. In that case, these Muslims parents had to negotiate their action between using stick and carrot approach, and for that reason, some of them lighten their expectation on their children's religiosity; it was sufficient for them if their children were aware of their religious backgrounds and cultural values. In spite of negotiation taking place in implementing Islamic education, most Muslim youths in the study felt blessed being born and raised into Muslim families. They also see that being in the mosque or weekend school was advantagous although minor silent resistances occured as well, as voiced by some of them.

Although this study was conducted in such away following the academic standard, it also has some limitations in its nature. The participants of the study were only Indonesian Muslims confined in a particular Indonesian Muslim community in Victoria. Most of them visited the same Indonesian Islamic centers and were usually involved in the same cultural festivals and ceremonies. The study may unveil more complex results had the participants come from different communities and different states within Australia, and this opens light for future studies on similar issues. 


\section{References}

Akhtar, Mohammad, ed. Muslim Family in a Dilemma: Quest for a Western Identity. Lanham, Boulder, New York, Toronto, Plymouth, UK: University Press of America, Inc, 2007.

- - , ed. "The Identity Conflict for Muslims in the West." In Muslim Family in a Dilemma: Quest for a Western Identity. Lanham, Boulder, New York, Toronto, Plymouth, UK: University Press of America, Inc, 2007.

Al-Attas, Syed M. Naquib. "Preliminary Thoughts on the Nature of Knowledge and the Definition and Aims of Education." In Aims and Objectives of Islamic Education, edited by Syed M. Naquib Al-Attas. Jeddah: King Abdul Aziz University, 1977.

Alavi, Hamid Reza. "Nearness to God: A Perspective on Islamic Education, Religious Education." Religious Education: the Official Journal of the Religious Education Association 103, no. 1 (2008): 5-21.

Ali, Syed. "Why Here? Why Now? Young Muslim Women Wearing Hijab." The Muslim World 95, no. 4 (2005): 515-530.

Anwar, Muhammad. "Muslims in Western States: The British

Experience and the Way Forward." Journal of Muslim Minority Affairs 28, no. 1 (2008): 125-137.

Basit, Tehmina N. Educational, Social and Career Aspiration. Cambridge: University of Cambridge, 1995.

- - - " “I Want More Freedom, but Not Too Much': British Muslim Girls and the Dynamism of Family Values." Gender and Education 9, no. 4 (December 1, 1997): 425-440. Accessed May 14, 2019. https://doi.org/10.1080/09540259721178.

Bayoumi, Moustafa. "Being Young, Muslim, and American in Brooklyn." In Being Young and Muslim: New Cultural Politics in the Global South and North, edited by Linda Herrera and Asef Bayat. Oxford, New York: Oxford University Press, 2010.

Becher, Harriet. Family Practices in South Asian Muslim Families: Parenting in a Multi-Faith Britain. New York: Palgrave Macmillan, 2008.

Collet, Bruce A. "Islam, National Identity and Public Secondary Education: Perspectives from the Somali Diaspora in Toronto, Canada." Race Ethnicity and Education 10, no. 2 (July 1, 2007): 
131-153. Accessed May 14, 2019. https://doi.org/10.1080/ 13613320701330668.

Cook, Bradley. "Islamic Versus Western Conceptions of Education:

Reflections on Egypt." International Review of Education 45, no. 3-4 (May 1, 1999): 339-357.

Doogue, Geraldine, and Peter Kirkwood. Tomorrow's Islam: Uniting Age-Old Beliefs and a Modern World. Sydney: ABC Books, 2005.

Douglass, Susan L., and Munir Shaikh. "Defining Islamic Education: Differentiation and Applications." Current Issues in Comparative Education 7, no. 1 (2004): 5-18.

Ekram, and Mohamed Rida Beshir. Meeting the Challenge of Parenting in the West: An Islamic Perspective. 4th ed. Beltsville: Amana Publication, 2009.

Franceschelli, Michela, and Margaret O'Brien. “'Being Modern and Modest': South Asian Young British Muslims Negotiating Multiple Influences on Their Identity." Ethnicities 15, no. 5 (October 1, 2015): 696-714. Accessed May 14, 2019. https://doi.org/10.1177/1468796815584423.

Halstead, J. Mark. "Toward a Unified View of Islamic Education." Islam and Christian-Muslim Relations 6, no. 1 (1995): 25-43.

Harris, Anita, and Ameera Karimshah. "Young Muslims, Stigma and the Work of Normality." Sociology 53, no. 4 (August 1, 2019): 617-633. Accessed December 14, 2019. https://doi.org/10.1177/0038038518800632.

Hassan, Riaz. Inside Muslim Minds. Carlton: Melbourne University Press, 2008.

Hilgendorf, Eric. "Islamic Education: History and Tendency." Peabody Journal of Education 78, no. 2 (April 1, 2003): 63-75. Accessed May 14, 2020. https://doi.org/10.1207/ S15327930PJE7802_04.

Hussain, Amjad. "Islamic Education: Why Is There a Need for It?" Journal of Beliefs \& Values 25, no. 3 (December 1, 2004): 317-323. Accessed May 14, 2019. https://doi.org/10.1080/ 1361767042000306130.

Kabir, Nahid Afrose. "Muslim Women in Australia, Britain and the United States: The Role of 'Othering' and Biculturalism in Identity Formation." Journal of Muslim Minority Affairs 36, no. 4 
(October 1, 2016): 523-539. Accessed May 14, 2019. https://doi.org/10.1080/13602004.2016.1257683.

- - - Young British Muslims: Identity, Culture, Politics and the Media. Edinburgh: Edinburgh University Press Ltd, 2010.

Kay, Tess. "Daughters of Islam: Family Influences on Muslim

Young Women's Participation in Sport." International Review for the Sociology of Sport (June 29, 2016). Accessed May 14, 2019. https://journals.sagepub.com/doi/10.1177/1012690207077705.

McGown, Rima Bern. Muslim in the Diaspora: The Somali Communities of London and Toronto. Toronto, Buffalo, London: University of Toronto Press, 1999.

Mishra, Smeeta, and Faegheh Shirazi. "Hybrid Identities: American Muslim Women Speak." Gender, Place \& Culture 17, no. 2 (April 1, 2010): 191-209. Accessed May 14, 2019. https://doi.org/10.1080/09663691003600306.

Muhaimin. Nuansa Baru Pendidikan Islam: Mengurai Benang Kusut Dunia Pendidikan. Jakarta: RajaGrafindo Persada, 2006.

Sartawi, Mohammed, and Gordon Sammut. "Negotiating British Muslim Identity: Everyday Concerns of Practicing Muslims in London:" Culture \& Psychology (December 11, 2012). Accessed May 14, 2019. https://journals.sagepub.com/doi/10.1177/ $1354067 X 12456714$.

Sirin, Selcuk R., and Michelle Fine. Muslim American Youth: Understanding Hyphenated Identities Through Multiple Methods. New York, and London: New York University Press, 2008.

Stewart, Sunita Mahtani, Michael H. Bond, L. M. Ho, Riffat Moazam Zaman, Rabiya Dar, and Muhammad Anwar. "Perceptions of Parents and Adolescent Outcomes in Pakistan." British Journal of Developmental Psychology 18, no. 3 (2000): 335-352. Accessed May 14, 2019. https://onlinelibrary.wiley.com/doi/abs/10.1348/0261510001657 33.

Tinker, Claire, and Andrew Smart. "Constructions of Collective Muslim Identity by Advocates of Muslim Schools in Britain." Ethnic and Racial Studies 35, no. 4 (April 1, 2012): 643-663. Accessed May 14, 2019. https://doi.org/10.1080/ 01419870.2011.577899. 
Woodlock, Rachel. “Praying Where They Don't Belong: Female Muslim Converts and Access to Mosques in Melbourne, Australia." Journal of Muslim Minority Affairs 30, no. 2 (2010): 265-278.

Yasmeen, Samina, ed. Muslims in Australia: The Dynamics of Exclusion and Inclusion. Melbourne: University of Melbourne Press, 2010.

Zine, Jasmin. "Safe Havens or Religious 'Ghettos'? Narratives of Islamic Schooling in Canada." Race Ethnicity and Education 10, no. 1 (March 1, 2007): 71-92. Accessed May 14, 2019. https://doi.org/10.1080/13613320601100385. 